\title{
Electronic Registries of Registration Authorities as a Factor in the Formation of the Proposals in the Primary Residential Real Estate Market
}

\author{
Lukashenok T.R.* Rosenko S.V.
}

\author{
Ural State University of Economics, Yekaterinburg, Russia \\ *Corresponding author. Email: tanalukas@mail.ru
}

\begin{abstract}
The purpose of the article is to study and justify the necessity of using electronic registries of registration authorities in the process of generating proposals on the primary residential real estate market. The article analyzes the possibilities of using electronic registers of registration authorities with companies-developers of the city of Yekaterinburg. The authors have developed a methodology for developers to use the data contained in the registers of registration authorities with the aim of constructing housing that meets the real needs of the population. Based on the results of the study, the form and structure of the modified data upload from the Unified State Register of Real Estate under an equity agreement is proposed, the implementation of which by the state registration authorities will optimize the work of data analysis to generate relevant, relevant to the actual demand of the population supply in the primary residential real estate market.
\end{abstract}

Keywords: electronic registers, registration authority, Unified State Register of Real Estate, primary

residential real estate market

\section{INTRODUCTION}

The Russian economy is characterized by regional, local differences and a large degree of economic heterogeneity. In this connection, when studying the real estate market of the Russian Federation, it is advisable to take into account the specifics of each region and location separately and carry out a detailed analysis of the conditions that have a direct impact on the formation of the real estate market, taking into account the peculiarities of the territories development.

One of the promising and rapidly developing segments of the real estate market is the primary residential real estate one[1]. This is due to the fact that housing is the basic need of the population, while living in real estate that meets modern standards of planning the necessary elements of a house and public infrastructure, which is inherent in modern construction, is the desire of the majority of the population.

Currently, in the context of increasing competition, it is important for developers to formulate a proposal in the primary residential real estate market that meets the needs of the population. This circumstance is decisive in choosing the location, volume of construction, quadrature and functional zoning of the space of primary residential real estate premises.

As one of the factors contributing to the formation of an up-to-date offer on the primary residential real estate market, it is advisable to consider the use of electronic registries of registration authorities. In the Russian
Federation, such registers include the Unified State Register of Real Estate, the maintenance of which is legally assigned to the Federal Service for State Registration, Cadastre and Cartography (hereinafter referred to as the Rosreestr). EGNR is a state information resource containing data on real estate in the Russian Federation.

As one of the factors contributing to the formation of an up-to-date offer on the primary residential real estate market, it is advisable to consider the use of electronic registries of registration authorities. In the Russian Federation, such registers include the Unified State Register of Real Estate, the maintenance of which is legally assigned to the Federal Service for State Registration, Cadastre and Cartography (hereinafter referred to as the Rosreestr). EGNR is a state information resource containing data on real estate in the Russian Federation.

Currently, Rosreestr successfully implements various digital technologies, including maintaining the USRN in electronic form with the ability to provide information through online services $[2 ; 3]$. However, most of the participants in the primary real estate market have no idea about the possibility of using electronic services to strengthen their competitive positions [4].

\section{RESEARCH METHODOLOGY}

In the course of the work at the article, the authors used the methods of scientific abstraction, induction and deduction, analogy and generalization, systemic, economic, 
organizational, functional analysis, which made up the research methodology.

\section{RESEARCH RESULTS}

As a result of the study, the authors identified the stages of the formation by developers of proposals in the primary residential real estate market and determined the possibility of using the information contained in the USRN.

At the first stage, constructors develop a project for the development of residential real estate and form its flatography, at the second - determine a marketing policy. The flatography (or the flat mapping) is a complex of space-planning, architectural, structural, economic solutions selected during construction, as a result of which the ratio of apartments of different rooms, areas, planning decisions is determined.

For the formation of a competent proposal in the primary residential real estate market, the developer uses a large data array, which is the result of a study of consumer activity in the population; socio-demographic studies; focus groups with an assessment of planning decisions; assessment of location by the location of the land, etc. [5]. However, when forming the proposal, it is advisable to use the USRN information as additional information. They are necessary for conducting competitive monitoring to identify the most liquid objects and determine the speed of their implementation, which allows to make a decision on the choice of the class of housing being built and its characteristics.

There is an example of the use of USRN information by

developers. Knowing the starting date of sales of the

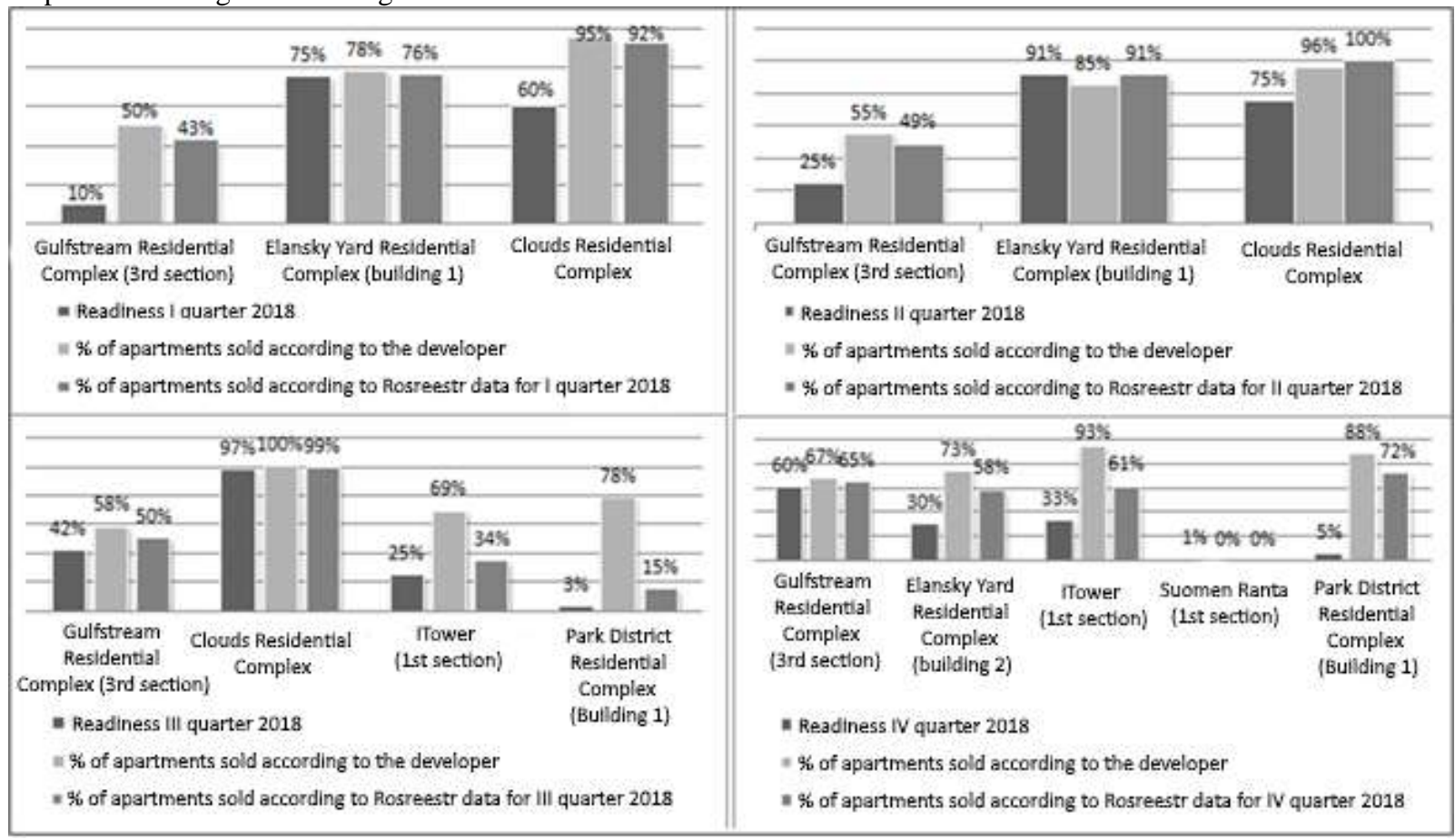

Figure 1 Percentage of apartments sold in the district Bus Station in the period I - IV quarter of 2018 property according to the project declaration of the competitor, the developer planning the construction requests an extract from the USRN on the object (residential complex of the competitor) in the location of his land. The extract from the USRN shows the dates of transactions for a residential complex erected by a competing developer. So, if according to the USRN, next to the land plot of the builder in the neighboring residential complex, the population sold 1-room apartments with an area of 40 square meters in the shortest time (the first for 3-4 months from the start of sales) m., this indicates a high demand for apartments with this room and area in the specified location. Based on this analysis, the developer can form a flatography containing apartments liquid by their characteristics.

Besides, it is advisable to use the analysis of the USRN information for developers to formulate an effective marketing policy, taking into account the monitoring of the marketing policies of competitors, as well as the correlation of prices for real estate. This is due to the ratio of sales windows of competing developers with data on the number of apartments sold based on USRN information.

It is advisable to consider the importance of USRN information for the formation of offers in the primary residential real estate market using a specific example: Yekaterinburg, the Gulf Stream residential complex (Figure 1). This residential complex is located in the Bus Station district, which is equated to the center of the city of Yekaterinburg and has interest from the residents of the city, which is explained by the large volume of development of the district, the developed transport network and the presence of a large number of infrastructure objects. 
to the USRN, you can determine the actual sales and understand the marketing moves of the developer. Thus, taking into account these data, the developer can correctly

and at the construction stage, despite the high cost of the location, the object is in demand among the population (Figure 2). shows the ratio of the percentage of apartments $[6 ; 7]$. It is worth noting that the data of the developer does not always coincide with the data of Rosreestr. According formulate his proposal on the primary residential real estate market, which will meet the needs of the population. The data obtained during the analysis confirm that the developer, using the USRN data, forms the current offer,

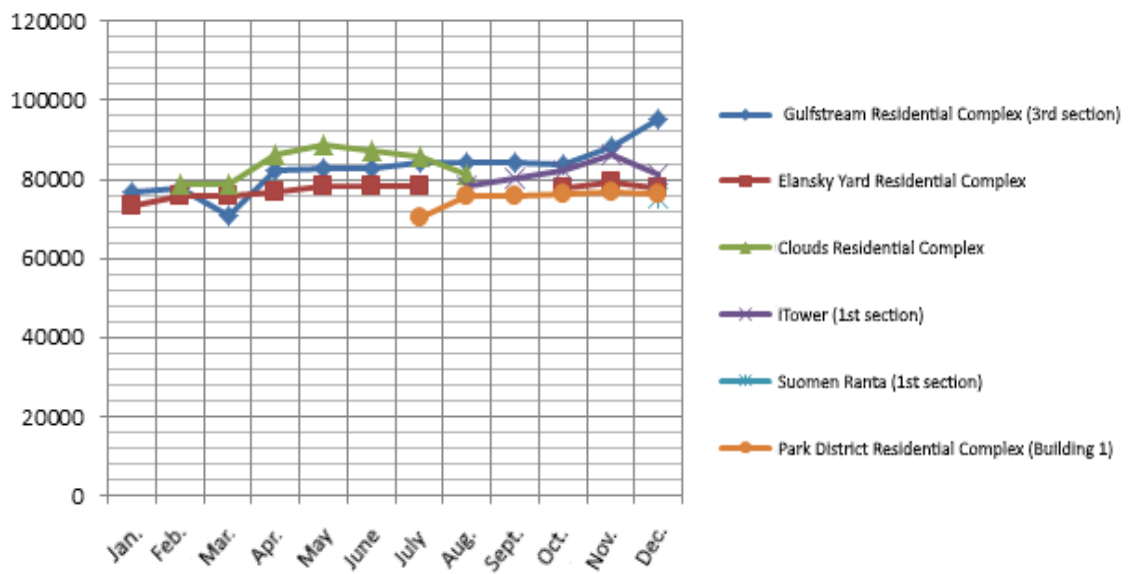

Figure 2 Cost of 1 sq.m. in the district Bus station for 2018, rubles.

Based on the data in Figure 2, it is worth noting that all residential complexes in this location are in the same price range. However, in March 2018 in the Gulf Stream residential complex (section 3 ) there is a decline and the cost of sq.m. during this period is reduced by 7,000 rubles. In the period April-June, the price range of the LCD Gulf Stream (section 3) is between the LCD Elansky Yard and LCD Clouds, that is, the LCD Gulf Stream (section 3) has an average price in the market in comparison with competitors. Further, an increase in the cost of 1 sq.m. in this residential complex $[8 ; 9 ; 10]$.

In Figure 3 we can see how many apartments the developer put into his residential complex, taking into account USRN data.

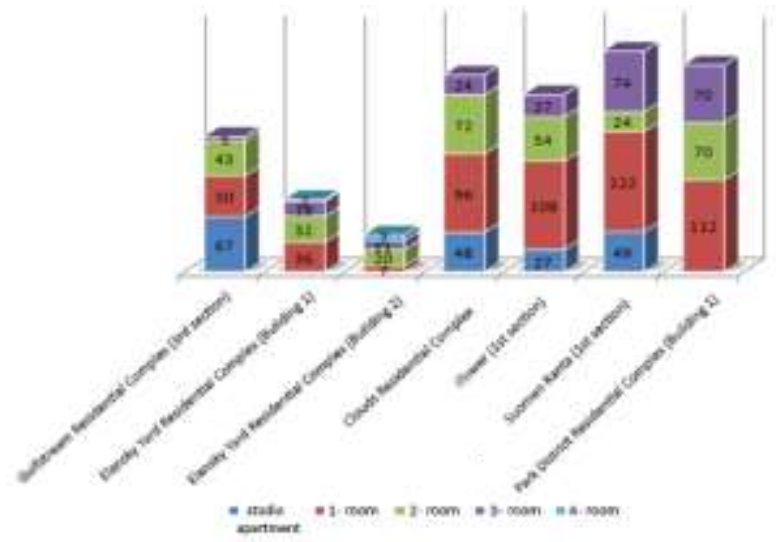

Figure 3 The number of apartments in residential complexes according to the project declaration of developers in the district Bus Station, pcs.
Based on the data in Figure 3, it is worth noting that the developer Sinara-Development created the Gulf Stream flatography (section 3), based on the analysis of competitors' flatography analysis, and selected the actual number of apartments in the context of studios, 1bedroom, 2-bedroom, etc. The developer SinaraDevelopment, as a result of the analysis, concluded that in this location the studios have in the residential complexes Clouds, iTower (section 1) and SuomenRanta (Finnish coast) (section 1), as well as in the other residential complexes, the largest percentage have 1- bedroom apartments, and took the decision to lay $41 \%$ of studios and $30 \%$ of 1-room apartments in his flatography; the developer chose the average number of 2-room apartments for all residential complexes and put this number into its apartment building. The developer analyzed that 3-room and $4+$-room apartments are not well sold in this location, therefore, he introduced only 5 apartments with such characteristics into his flatography[11].

The study revealed that about $15-20 \%$ of developers use the USRN data, mainly developers who implement largescale projects, or developers who have a large number of projects.

The lack of a unified methodology for the formation of cartography and the definition of marketing policies based on USRN data significantly complicates the use of such information by construction companies.

According to the results of the study, the authors propose an algorithm for the formation by developers of proposals in the primary residential real estate market using information from the USRN: 
- clarification of the location of the land provided for the construction of residential real estate;

- identification of similar residential properties commissioned by competing developers;

- $\quad$ request for information from the USRN regarding residential properties of competing developers: transaction dates, apartment areas, number of rooms, etc .;

- $\quad$ correlation of the start time of sales with the dates of transactions and identification of the type of apartments (area, number of rooms, etc.) that have the shortest exposure time;

- formation of our own cartography, taking into account the results;

- monitoring the marketing policies of competitors, the formation and adjustment of their own marketing policies;

- adjustment of prices for real estate based on the correlation of the sales window with USRN data.

- formation of supply by developers, taking into account the algorithm developed by the authors, will satisfy the actual demand of the population and reduce the existing imbalance of supply and demand in the primary residential real estate market.

Currently, in the primary market of residential real estate in Yekaterinburg there is a glut of supply [12]. This is due to the introduction of escrow accounts: in order to fall under previously accepted standards, developers were in a hurry to introduce their projects to the market, thereby oversaturated it.

Under the conditions of market oversaturation, the solution of the question of the formation of an actual offer corresponding to the real needs of the population becomes especially important and timely [13].

It is worth noting that, along with the lack of a clear methodology for using USRN data in the process of generating proposals, developers are faced with another problem - the complexity of the analysis of the data provided.

Thus, the USRN data requested by electronic resources currently has the form shown in Figure 4.

\begin{tabular}{|c|c|c|c|c|c|c|}
\hline Request number & Date & Cadaster/conditions number & Description of object. & abject address & Boom No & Hoor \\
\hline $80-8915 \mathrm{~m}^{4}$ & 22.05 .2019 & & \multicolumn{2}{|c|}{ 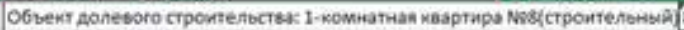 } & & 2 \\
\hline $90-89157774$ & 22.05 .2019 & & \multicolumn{2}{|c|}{ 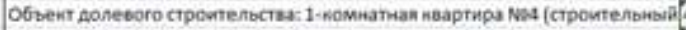 } & & 1 \\
\hline $80-89157774$ & 22.05 .2019 & & \multicolumn{2}{|c|}{ 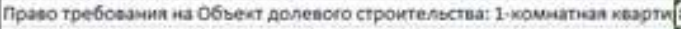 } & & 2 \\
\hline $80-8915774$ & 22.05 .2019 & & \multicolumn{3}{|c|}{ 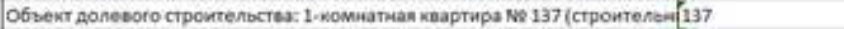 } & 16 \\
\hline $80-8915 \mathrm{~mm}$ & 22.05 .2019 & & \multicolumn{3}{|c|}{ 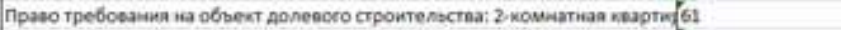 } & 3 \\
\hline 80-59157m4 & 22.05 .2019 & & \multicolumn{3}{|c|}{ 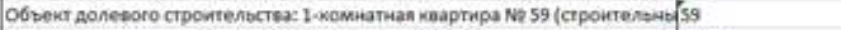 } & 7 \\
\hline $80-59157 / 74$ & 2205.2019 & & \multicolumn{3}{|c|}{ 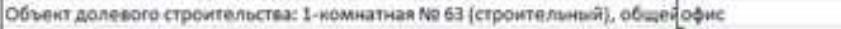 } & 3 \\
\hline $80-5915 m / 4$ & 22.05 .2019 & & \multicolumn{3}{|c|}{ 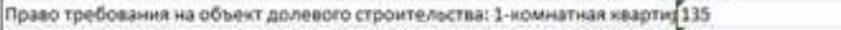 } & 16 \\
\hline $80-59157 m 4$ & 2205.2019 & & \multicolumn{3}{|c|}{ 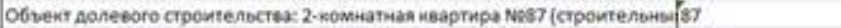 } & 10 \\
\hline $30-8915 \mathrm{mi}$ & 22.06 .2019 & & \multicolumn{3}{|c|}{ 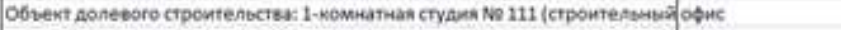 } & $\mathbf{u}$ \\
\hline $20-8915 \mathrm{ma}$ & 2205.2019 & & \multicolumn{3}{|c|}{ 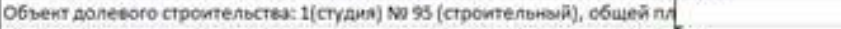 } & 11 \\
\hline $30-89157774$ & 22.05 .2019 & & \multicolumn{3}{|c|}{ 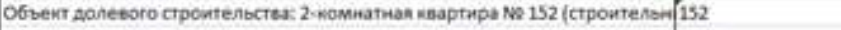 } & 18 \\
\hline $80-89157774$ & 22.05 .2019 & & \multicolumn{3}{|c|}{ 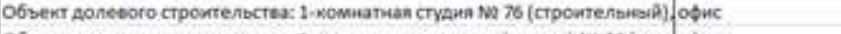 } & 9 \\
\hline 80.-59157774 & 22.05 .2019 & & \multicolumn{3}{|c|}{ 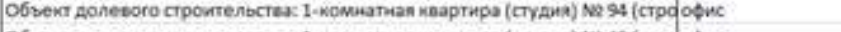 } & a1 \\
\hline $80-59157774$ & 22.05 .2019 & & \multicolumn{3}{|c|}{ 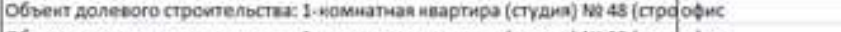 } & 6 \\
\hline $80-59157774$ & 22.05 .2019 & & \multicolumn{3}{|c|}{ 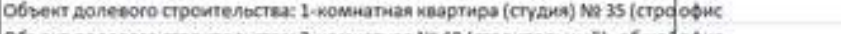 } & 5 \\
\hline $80-8915 \mathrm{~mm}$ & 22.05 .2019 & & \multicolumn{3}{|c|}{ 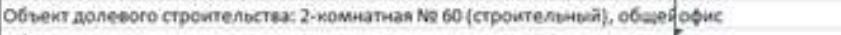 } & 7 \\
\hline $80-8915 \mathrm{~ms}$ & 22.05 .2019 & & \multirow{2}{*}{\multicolumn{3}{|c|}{ 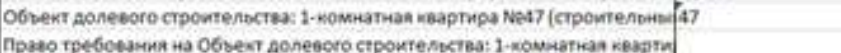 }} & 5 \\
\hline $80-5915 m 4$ & 2205.2019 & & Прасо требосамия на о6ье & & & 13 \\
\hline 30-6915 $7 \mathrm{~m}_{4}$ & 22.05 .2019 & & O6seкr Aonetoro crponter & 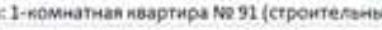 & & 11 \\
\hline $80-59157774$ & 22.06 .2019 & & 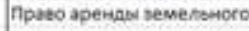 & ra cornacieo Aorosopy aptistibi sevenoweoro & & \\
\hline 80-8915T74 & 2200.2019 & & O6sent aonetoro crpontes & 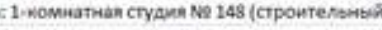 & & 17 \\
\hline $80-8915777 \mathrm{M}$ & 22.05 .2019 & & O6zект далевого строител & 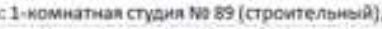 & opue & 11 \\
\hline 80.69157774 & 22.05 .2019 & & 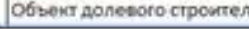 & 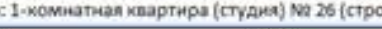 & qoфuc & 4 \\
\hline Apart. size [Rooms & & Right halder & & пpaвo & & Date of reglastration \\
\hline $29,67,1$ & Хиаркый Амитя & мй Алексанаровй & & Aоговор долевого мастия в строительстве 66:41:0 & 0604007:23-66/001/2018 & 2018.11 .06 \\
\hline $28,52[1$ & Kлецина Ксени & a Baotnbesma & & 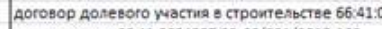 & 0604007:23-66/001/2019 & $\$ 2019.04 .05$ \\
\hline $29,67 \mathrm{~F}_{1}$ & "Tasnpombank" & (Aкциомерное общество), ИнН: 7744001497 & & o cuty sakens 66.41:0604007:23-66/001/2018-163 & & 2018.11 .06 \\
\hline $43,51 t_{1}$ & Deoktuctoo Han & atra Anenseeany & & Aoronop долевого участия в строительстве $66.41:$ & $0604007 \cdot 23 \cdot 66 / 019 / 2018$ & 2018.01 .18 \\
\hline $71,97 / 2$ & Aventwmoe aкu, & 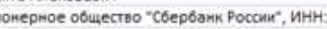 & 7707083893 & 8 cony sanoma 66:41:0604007:23-66/001/2019-205 & & 2019.01 .30 \\
\hline $28,67 T_{1}$ & Tpernow Anekc & ей генмадьевин & & qосовор долевого พастия в строительстве 66:41: & $0604007: 23-66 / 001 / 2017$ & 2017.11 .07 \\
\hline $42,95 \sqrt{1}$ & תaspos Utops A & Mencamaposiny & & 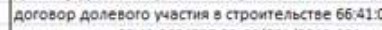 & $0604007 \cdot 23 \cdot 66 / 001 / 2018$ & 2018.03 .05 \\
\hline $42,899_{1}$ &  & чное акциомерное о6щестео), инн: 7702070 & & B cuty zakona $66: 41.0604007: 23-66 / 001 / 2019-191$ & & 2019.01 .17 \\
\hline $63,61 \sqrt{2}$ & Tолмачева Bar & ерия Cepreesna & & 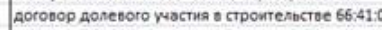 & $0604007 \cdot 23 \cdot 66 / 001 / 2018$ & 2018.11 .13 \\
\hline $29,49: 1$ & Корж Амитрий & Владимиировия & & договор долесого уастия в строительстве 66:41: & $0604007: 23 \cdot 66 / 001 / 2017$ & 2017.12 .05 \\
\hline 31,32 & EARадов Федор & Денисовим & & Aоговор долевого уастия в строительстве $66: 41: 0$ & $0604007: 23 \cdot 66 / 001 / 2017$ & 2017.12 .04 \\
\hline $72,74 / 2$ & Aнtoнова татье & ma Arexcaraposka & & Aоговор долевого үастия \& строительстве $66.41:$ & $0604007: 23-66 / 001 / 2018$ & 82018.01 .10 \\
\hline $28,39 \%$ & Anenceesa Cret & Enama Mrxaйnotma & & 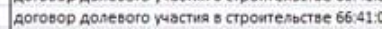 & $0604007 \cdot 23 \cdot 66 / 001 / 2018$ & 201801.10 \\
\hline 28,39$]_{1}$ & Beчkanos Cepre & :"̈ Anekcarapobry & & дотовор долепого үуастия o строительстве $66: 41: 0$ & $0604007 \cdot 23 \cdot 66 / 001 / 2018$ & $\$ 2018.02 .01$ \\
\hline $29,577_{1}$ & Филинова Елема & Anatonьeвira & & договор долевого участия в строительстве 66:41: & $0604007 \cdot 23 \cdot 66 / 001 / 2018$ & 201802.09 \\
\hline $29,677_{1}$ & Oиленова Esem: & Anatonseska & & 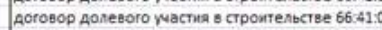 & $0604007: 23-66 / 001 / 2018$ & 2018.02 .01 \\
\hline $63,672_{2}^{2}$ & Opgos Arapeñ t. & денисович & & Aоговор долевого чизстия \& строительстве $66: 41.0$ & $0604007: 23-66 / 001 / 2018$ & 2018.04 .06 \\
\hline 43,695 & Kapunoso Anar & 19 Ряшитоена & & 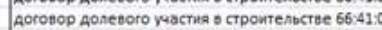 & $0604007.23 \cdot 66 / 001 / 2019$ & 92019.0122 \\
\hline $28,35 \frac{1}{1}$ & POQROOMOER APU & na Cepreenna & & D cony sakona $66: 41: 0604007: 23-66 / 001 / 2018-35$ & & 201801.09 \\
\hline 43,53$]_{1}$ & Федорова Ири & wa Сергеesma & & 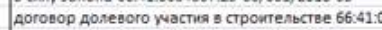 & $.0604007 \cdot 23-66 / 001 / 2018$ & $\$ 2018.02 .08$ \\
\hline & Ууастники Аоле &  &  & s cany закона 66:41:0606007:23-66/001/2017-2 & & 2017.03 .24 \\
\hline $28,35 t_{1}$ & Crenamosa Bep & Teoprnesna & & 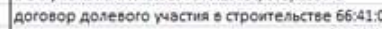 & $.0604007: 23-66 / 001 / 2018$ & 2018.01 .09 \\
\hline $29,45 t_{1}^{4}$ & Paбas Akactrach & atoperna & & Aоговор долевого участия о строительстве 66:41: & $0604007 \cdot 23-66 / 001 / 2018$ & 2018.01 .10 \\
\hline $27,380_{1}$ & 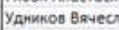 & пев Михай́овевч & & договор долевого частия в строительстве 66:41: & $.060400723-66 / 016 / 2018$ & 2018.09 .24 \\
\hline 43,69 & БанK BTE (m) & иное акционерное общество), ИнН: 7702070 & & Scury sanona 66:41:0604007:23-66/001/2018-117 & & 2018.04 .06 \\
\hline $27,43 / 1$ & 8аxрvшеesa War & нна Владиславовна & & договор долевоro พастия в строительстве 66:41: & $0604007 \cdot 23-66 / 001 / 2018$ & 2018.02 .12 \\
\hline 28,67 & Enarner Amutponä & i Гемmaдpesin & &  & $0604007 \cdot 23 \cdot 66 / 001 / 2017$ & 2017.12 .04 \\
\hline $27,51 / 1$ & rapkaчes Aemus: & curopernu & & Aоговор долевого үастия o строительстее $66: 41: 0$ & $0604007: 23 \cdot 66 / 001 / 2018$ & \\
\hline 30,46 & npokonenko Ak & одмила Владимировке & & договор долесого ччастия в строительстве 66:41: & $0604007 \cdot 23 \cdot 66 / 001 / 2018$ & \\
\hline fa $61 t_{2}$ & 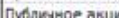 & 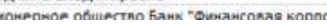 & 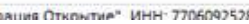 & 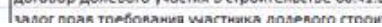 & 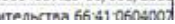 & 2018 1113 \\
\hline
\end{tabular}

Figure 4 Uploading data from Rosreestr under an equity agreement 
- Information about the number of rooms is not always displayed reliably. So, an apartment of 27.38 square meters is a studio, but is indicated in the extract from the USRN as a 1-bedroom apartment.

- There are two separate registries: under a contract of sale and an agreement on shared construction. These registries are not synchronized.

However, the fact that the date of registration of the object (month, year) and the number of registered transactions and is indicated in the extract from the USRN is an undoubted plus and it makes it possible to formulate a proposal based on data from the USRN.

In order to systematize the data necessary for analytical work, the authors developed an improved form and structure for downloading data from the USRN, which can be implemented in the Rosreestr system (Figure 5). This will help make data uploading efficient and optimize resources for analytical work [14].

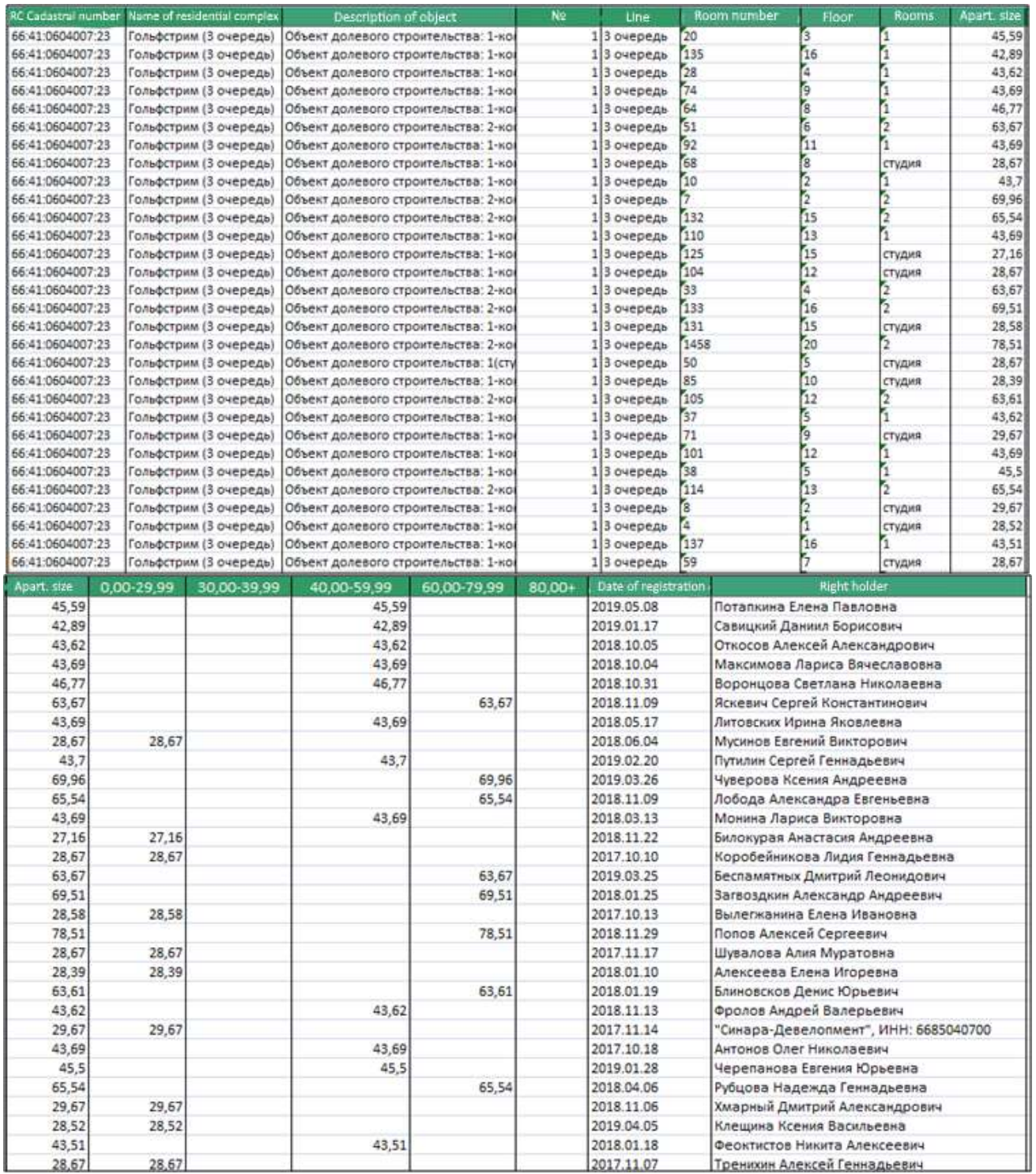

Figure 5 Modified data upload from Rosreestr under an equity agreement 
The unloading proposed by the authors contains the name of the residential complex. Also, all transactions on the object, i.e. this unloading should be for the whole city, which will allow analyzing data in the context of the entire territory, filtering out the necessary residential complex, which has a certain location, and marking which apartments were registered in Rosreestr, i.e., sold. The ROM number is displayed in a separate column to see how many sections are in the property.

Room number, floor, number of rooms, date of registration, description of the object remains unloaded unchanged. The area also remains in the proposed unloading, but systematization by the area of the object is added. Ranges from 0 to 30 square meters suggest a studio, 30-40 square meters. m. - these are 1-room apartments or can be studios, in this case it depends on the flatography of a certain residential complex. For example, in the Gulf Stream LCD (section 3), studios are in the range from 29 to 40 square meters.

Thus, this extract contains a lot of data, using which developers can correctly assess the situation on the primary residential real estate market and enter objects that will be in demand among the population. Accordingly, the market for primary residential real estate in Yekaterinburg will not be oversaturated with unclaimed facilities. It is assumed that this statement will be developed for the entire city and will contain information for each residential complex.

\section{DISCUSSION OF THE RESULTS}

The research results are of high theoretical and practical importance.

This study was discussed with representatives of companies involved in the provision of analytical data for developers in the city of Yekaterinburg, with the heads of real estate agencies in the city of Yekaterinburg.

\section{REFERENCES}

[1] I.R. Lyapina, S.A. Orlova, E.E. Semenova, M.A. Stepanova, The State and Development of the Real Estate Market, Lecture Notes in Networks and Systems Growth Poles of the Global Economy: Emergence, Changes and Future Perspectives. Plekhanov Russian University of Economics, Luxembourg, 2020, pp. 97107

[2] V.V. Gapchukova, The relevance of creating a federal state information system for the unified state register of real estate, Young Scientist, 2 (240) (2019) 113-115

[3] V.G. Antonov, N.K. Atabekova, U.A. Pozdnyakova, A.I. Novikov, Digital Human: Principles of Behavior in
The questions investigated in this article are reflected in the materials used to form the training course "Real Estate Economics", "Fundamentals of Realtor Activities" in the direction "Land Management and Cadastres".

\section{CONCLUSIONS}

Based on the foregoing, the authors concluded that electronic registers of registration authorities are essential in creating proposals on the primary residential real estate market.

Analyzing the massive database of the Unified State Register of Real Estate, developers have the opportunity to research the market and, based on the results, create relevant objects that can satisfy the demand of the population. Using USRN information allows developers to study in detail the location selected for the construction of real estate, determine the volume and speed of sales, as well as the most popular characteristics of residential real estate. On the basis of the data obtained, developers have the opportunity to create up-to-date flatography, form an effective marketing policy, set optimal prices, as a result of which objects will be in high demand among the population.

The algorithm developed by the authors for the use of USRN data in the process of creating a proposal on the real estate market will allow developers to make the use of data accessible and understandable.

An improved form of extract from the USRN will help market participants optimize the resources spent on analytics, plan the flatography quality and make sales more effective.

The proposed measures will help stabilize the situation in the primary residential real estate market in terms of supply and demand.

the Market and Internal Contradictions, Lecture Notes in Networks and Systems, 87 (2020) 161-167

[4] I.V. Bezdeleva, Influence of digital technologies on the residential real estate market of the Russian Federation, Innovation and investment, 1 (2020) 275276

[5] D.V. Dianov, Formation of a system of statistical indicators for creating objects of the primary real estate market, Statistics and Economics, 17 (1) (2020) 14-24

[6] Information resource for the selection and comparison of new buildings Ingraficon.ru [Electronic resource]. https://ingraficon.ru

[7] KADNET - Electronic document management with Rosreestr [Electronic resource]. https://www.kadnet.ru 
[8] Elansky Yard - residential complex [Electronic resource]. https: //elanian court.rf

[9] Residential complex Gulf Stream [Electronic resource]. https://zhiloy-kompleks-golfstrim-3ochered.sinara-development.ru.

[10] YIT Uralstroy in Yekaterinburg [Electronic resource]. https://ekb.yit.ru

[11] Residential complex iTower - innovative towers [Electronic resource]. http://itower.life

[12] Office of the Federal State Statistics Service for the Sverdlovsk Region and Kurgan Region [Electronic resource]. http://sverdl.gks.ru

[13] T.R. Lukashenok, S.V. Rozenko, Features of the functioning of the primary residential real estate market in the region, Science without Borders, 5 (33) (2019) 30-36

[14] A.P. Pavlyukova, D.A. Gora, D.A. Zamotaylova, Using Distributed Registry Technology as an Optimization of the State Real Estate Register, Digitalization of Economics: Directions, Methods, Tools: Proceedings of the II All-Russian Student Scientific and Practical Conference, 2020, pp. 254-258 